\title{
STATE OWNED ENTERPRISES (BUMN) REFORM IN INDONESIA: \\ PRIVATIZATION FAILURES
}

\author{
Oleh: \\ Alfiana Yuli Efiyanti*)
}

\begin{abstract}
It is realized that State Owned Enterprises (BUMN) is one of the most important asset of Indonesia. Those firms are expected to contribute and generate a significant number of revenue. They are also demanded as a public needs provider. However, there are many evidents that the performance of BUMN, that historically heritage from the Dutch colonialist, is not satisfactory.

In 1982 when Indonesian economy suffered because of the sharp fall in oil prices, issues regarding the inefficiency of BUMN were widespread due to the lack of their performance. As a result, the government instructed all ministries to increase the productivities and efficiency of BUMN in their departments. Some restructuring and reforming programs including privatization have taken place. However, without any clear objectives, the program was not seriously monitored.

Only in mid 1997, when the Asian crises hit Indonesia economy, government needs tool in stabilizing and restructuring the economy. Privatization program then emerged and was not postponed.

This report of research presents the failure of privatization program that was adopted during the Asian Crises. It is judged as a failure because the "big bang" action, did not meet both the government written objectives and the theories of privatization.
\end{abstract}

Key Word: State Owned Enterprises (BUMN), reforms, restructures, privatization program

\section{Introduction}

The status of Indonesian State Owned and Enterprises (SOEs) or Badan Usaha Milik Negara (BUMN), whether they are privatized or remain in the government's hand, has been the most controversial issue for the past 7 years. Like in many other countries, privatization has divided the players into two groups. Each groups present their own strong arguments. Looking at the Indonesian experience itself, it has been widely known that privatization has contributed in generating revenue, but also has meet strong resistances. The resistance came not only from the people and employees of the BUMN, but also from politicians and decision makers from several levels of government institutions who has variety of interests.

As a result, the Minister of BUMN, who is responsible for the operation of BUMN, has been facing some significant difficulties in making decisions. The ambiguity of government for implementation privatization program have resulted into different practices from the objectives iconsistent of privatization.

Commitment to privatization already began in mid 1980s when the government issued the Presidential instruction No. 5/1988. However, in that instruction there was no 
clear definition and objectives for privatization. The instruction mainly emphasized to the restructuring and reforming of the economic sector in order to adopt liberalisation and free market. As a result, there was no significant number of BUMN privatized at that time. The first privatization only took place in 1992 when PT Semen Gresik offered its shares in domestic market through Initial Public Offering - IPO.

There was no big change in the policy until 1997, when the Indonesian economy suffered from the Asian crisis. The government needed tools in stabilizing and restructuring the economy. Privatization program then emerged and was not postponed.

There were some reasons why the Indonesian government implemented privatization programs It could be summarized into two reasons, internal pressures and external pressures. Internal pressures were mainly caused by the financial condition of Indonesia. Financial condition refers to the financial condition of the government such as balance of payment deficit, budget deficit and shortage of funds in public enterprises.

Most BUMN, supporting by government regulation, have enjoyed a great market share and operated their business with few or no competition. On the other word, BUMN have monopolised some sectors of the economy. Lack of competition led some problems. No motivation for the employees which resulted in low productivity and low of the quality of products and services. In this case, the existing of BUMN has created heavy burden for the government rather than benefited.

The external pressures have come from international institutions. Like in many developing countries, Indonesia received grants and loans in order to run general developing programs, especially when the crises hit the country in 1997/1998. The supporting institutions such as IMF, World Bank and USAID helps Indonesian economy and suggested to the Indonesian government to adopt the ideology of free market. Free market and global competition was needed to improve efficiency and productivity. In order to reach its purposes, unhealthy competition or monompoly of BUMN operation, and the role of government in economy must be abolished.

For the past seven years the privatization policy has been implemented, but the government still faced dilemma in making decisions. The conflict between those who support privatization and those who oppose it continue to widen as a national issue.

This report presents the existing of BUMN including its historical background and performance, restructuring and reformation policy before the crisis, and privatization program which have been adopted by the government pursued the Asian crisis. The theories, including the objectives, reasons and the practice in comparison, and evaluate 
whether the program was successful achieve the objectives government has been consistent with its objectives or not. The major question being answered here is:

- Why has the practice of privatization program implemented in been Indonesia not achieved government objectives?

\section{Theoretical Foundation}

The wide definition of privatization was noted by E.S. Savas, "Privatization is a dynamic concept that in the simplest sense means changing from an arrangement with a government producer to one with a private producer." (Savas, 2000, 104) However, he continued that the forms of privatization could be widened including delegation, divestment and displacement. Deeply he also presented the advantages and disadvantage of different privatization methods, that is shown in the below table.

Table 1. Methods of Privatization

\begin{tabular}{|c|c|c|}
\hline Method & Advantages & Disadvantages \\
\hline Contract & $\begin{array}{l}\text { Increase productivity, save } \\
\text { money, it is transparent }\end{array}$ & Probable worker opposition \\
\hline Franchise by consession & $\begin{array}{l}\text { Brings expertise, technology, } \\
\text { investment, cuts costs }\end{array}$ & Probable worker opposition \\
\hline Franchise by Lease & $\begin{array}{l}\text { Brings expertise, technology, } \\
\text { cuts costs }\end{array}$ & Probable worker opposition \\
\hline Grant & $\begin{array}{l}\text { Less costly than direct } \\
\text { government provision }\end{array}$ & $\begin{array}{l}\text { Continued cost to } \\
\text { government, not very } \\
\text { transparent }\end{array}$ \\
\hline Voucher & $\begin{array}{l}\text { Gives recipients choice, saves } \\
\text { money, corruption free }\end{array}$ & $\begin{array}{l}\text { Continued cost to } \\
\text { government }\end{array}$ \\
\hline Mandate & $\begin{array}{l}\text { Imposes full cost on private } \\
\text { sector }\end{array}$ & $\begin{array}{l}\text { Imposes full cost on private } \\
\text { sector, masks government } \\
\text { role }\end{array}$ \\
\hline Sale to Joint Venture & $\begin{array}{l}\text { Brings expertise, technology, } \\
\text { investment, raises some cash, } \\
\text { government retains part } \\
\text { ownership }\end{array}$ & not very transparent \\
\hline Sale to Private Buyer & $\begin{array}{l}\text { Brings expertise, technology, } \\
\text { investment, raises cash }\end{array}$ & $\begin{array}{l}\text { Possible worker opposition, } \\
\text { may not attract buyers, not } \\
\text { very transparent }\end{array}$ \\
\hline Sale to the public & $\begin{array}{l}\text { Popular, transparent, raises } \\
\text { cash }\end{array}$ & $\begin{array}{l}\text { Suitable only for low-risk } \\
\text { situations, no new investment } \\
\text { in the enterprise }\end{array}$ \\
\hline $\begin{array}{l}\text { Sale to managers and } \\
\text { employees }\end{array}$ & $\begin{array}{l}\text { Retains operationg } \\
\text { experience, popular with } \\
\text { employees }\end{array}$ & $\begin{array}{l}\text { No new investment, expertise } \\
\text { or technology brought into } \\
\text { the enterprise }\end{array}$ \\
\hline $\begin{array}{l}\text { Sale to users or customers } \\
\text { cooperative }\end{array}$ & $\begin{array}{l}\text { Popular, gets rid of the } \\
\text { provlem, eliminates darin on } \\
\text { funds, raises cash, }\end{array}$ & \\
\hline
\end{tabular}




\begin{tabular}{|c|c|c|}
\hline & transparent & \\
\hline $\begin{array}{l}\text { Free transference to joint } \\
\text { venture }\end{array}$ & $\begin{array}{l}\text { Brings expertise, technology, } \\
\text { investment, government } \\
\text { reatins part of the ownership }\end{array}$ & Raises no revenue \\
\hline $\begin{array}{l}\text { Free transference to the } \\
\text { public }\end{array}$ & Popular with the public & $\begin{array}{l}\text { Retains management, no } \\
\text { revenue, no new investment } \\
\text { or expertise }\end{array}$ \\
\hline $\begin{array}{l}\text { Free transference to } \\
\text { employees }\end{array}$ & Popular with the employees & $\begin{array}{l}\text { no revenue, no new } \\
\text { investment or expertise, } \\
\text { unfair to the public }\end{array}$ \\
\hline $\begin{array}{l}\text { Free transference to users } \\
\text { or customers cooperative }\end{array}$ & $\begin{array}{l}\text { Popular, eliminates problem } \\
\text { and money drain, } \\
\text { transparent }\end{array}$ & Raises no revenue \\
\hline $\begin{array}{l}\text { Free transference to } \\
\text { original owner }\end{array}$ & Fair & Raises no revenue, unpopular \\
\hline Liquidation & $\begin{array}{l}\text { Gets rid of the problem, } \\
\text { raises some cash }\end{array}$ & Worker opposition \\
\hline Default & Subtle solution & Temporary public complaints \\
\hline Withdrawal & Can do gradually & Public complaints \\
\hline Deregulation & Good policy & $\begin{array}{l}\text { Complex, opposition from } \\
\text { vested interests }\end{array}$ \\
\hline
\end{tabular}

Source: E.S Savas, Privatization and Public Private Partnerships, 2000, page 139.

The emergence of privatization was advocated by an International institution, World Bank that claimed that the sale of publicly-owned assets allows improvement in the financial position of governments, and reduction government debts (Grant \& Quiggin, 2001).

The IMF definition of privatization, which was presented by G.A. Mackenzie, "Privatization is not supposed to be undertaken to fill a hole in the budget. Its purpose is to achieve a redeployment of assets in the economy from the public sector, where it is assumed that they are being used inefficiency, to the private sector, where it is expected they will be utilized more efficiently"(Mackenzei, IMF, 1997).

Ashley Brown, the Executive Director, Harvard Electricity Policy Group, JF Kennedy School of Government, Harvard University presented the rationale of privatization, which can be summarized as: "Sector ineffeicency, reduce political influence with sector operations, reduce opportunity for corruption, allow sector to function on a commercial basis, inability to attract sufficient capital on favorable terms to meet demand, international pressure to libralise, paying government debts, reallocation of resources of state, under capitalisation, ideology, labor and management, transfer of risks to private sector."

Tanri Abeng the former BUMN Minister has mentioned in his article that in response to the globalization of production, expenses, labour, information, and trade, there no denying that BUMN must be reformed, restructured and privatized. BUMN should be 
encouraged to operate as a corporation, run its business in profit oriented and have the ability to compete in the global market. (Abeng, 2000)

Under the supervision of Laksamana Sukardi, a Master Plan of BUMN was formed and updated in 2002. One of the mission of BUMN Ministry regarding restructuring and privatizing BUMN is in point $5 \mathrm{~b}$ : "Enhance corporate value by restructuring, privatization and business cooperation amongst SOEs based on sound business principles." (BUMN Master Plan 2002 - 2006, p.4). While the privatization itself is defined as "....the relinquishing of effective control over a company to a manager and private owner and commonly occurring once the majority shares in that company have been transferred to private ownership." (BUMN Master Plan 2002 - 2006, p 19).

In accordance with the all government regulations, presidential decrees, presidential instructions and the most recent House of Representative and Presidential decree no. 19/2003 concerning BUMN, the government defines privatization as the selling of BUMN which has the Persero status, either partial or entirely to the third party(s), in order to improve the efficiency, increase the value of the company, increase the benefits for the society and widen the ownership of the shares to the society.

Overall, based on BUMN Decree No. 19/2003 and BUMN Master Plan 2002 - 2006, government objectives of privatization can be summarized as follows:

1. To widen the ownership of BUMN Persero to the society

2. To increase the efficiency and productivity of the company

3. To create strong and healthy financial structure and financial management

4. To create healthy competitiveness in the industrial structure

5. To create global orientation of the Persero (PT)

6. To improve the environment of business, macro economics and market capacity

7. To improve the performance of the company and provide more valuable benefit

8. To increase the participation of the society over the Persero (PT)

9. To contribute financially to the state or to the company

10. Acceleration of good corporate governance principles

11. Opening access to international market

12. Transferring technology and best practices to BUMN

\section{Method of Composing this Report}

This report is structured as a confirmatory qualitative research.. Two types of data are combined, primary data and secondary data. Primary data was collected by direct and electronic interview and correspondence. Secondary data was compiling from the documents which were relation to the BUMN and privatization policy. The available data 
was then analyzed by comparing and confirming whether the practice of privatization has meet the government objectives.

This reseach is focus on the Privatization Public Policy, which include the BUMN ministerial and finance ministerial as the key informants, economics expertise as the supporting informant.

\section{Result of the Research}

Looking back at the historical background, most of the BUMN heritage were from the Dutch colonialist which were nationalized by president Soekarno. The nationalization itself have created some negative aspects in the performance of BUMN. As expressed by Thee Kian Wie, after some time of development, BUMN performance was not satisfactory. "Other problem is facing in results of nationalisation are Indonesian government possessed many companies in 'one blick of eyes'. In the development process, those companies, particularly in the new order era opened opportunities for corruption which are practiced by the politicians and government who treated BUMN as 'cash cows'. Consequently many BUMN did not operate efficiently, did not generate enough revenues for the state budget, but more burden for the government, as they must be subsidized in order to help their operation." (Thee Kian Wie, 2001)

In 1988, when Indonesian economy went slow down because of oil price fell down, government adopted restructuring and reforming policy in the economic sector. BUMN reform and privatization were included in that policy.

In that period of time, the action taken by the minister of Finance was preparing the companies to enter the open market and to be privatized. In order to strengthen the previous decree no. 740/KMK.00/1989, another decree issued by the Ministry regulations, that was decree no. 741/KMK.00/1989, concerned with simplification of control system, which contained of: 1) corporate plans, 2) shortening the policy decision-making process.

In practice, however, the reform and deregulation more concentrated in the private sector to open to the market. Table 2 summarizes the restructuring and deregulation program that indicates that there was no direct impact on BUMN restructuring

Table 2. Summary or Reform Measures

\begin{tabular}{|l|l|l|l|}
\hline Sector Reformed & Main Contents & Impacts \\
\hline Financial & - $\begin{array}{l}\text { Remove interest rate control for State } \\
\text { Banks* } \\
\text { 1 June, 1983 } \\
\text { Banking Regulation }\end{array}$ & $\begin{array}{l}\text { - } \\
\text { Reduce liquidity credit } \\
\text { Remove credit ceilings }\end{array}$ & $\begin{array}{l}\text { Rise in deposit rates } \\
\text { Some fall in intermediation } \\
\text { costs } \\
\text { In fact, liquidity credits } \\
\text { increased }\end{array}$ \\
\hline October, 1986 & - Removal of ceiling on Central Bank Swap & \\
\hline
\end{tabular}




\begin{tabular}{|c|c|c|}
\hline $\begin{array}{l}21 \text { October } 1988 \\
\text { (PAKTO - October } \\
\text { Package) }\end{array}$ & $\begin{array}{l}\text { - Open up licences for new banks, including } \\
\text { joint ventures } \\
\text { - Lending limits regulations } \\
\text { - Reserve requirement lowered }\end{array}$ & $\begin{array}{l}\text { - Opening up many banks and } \\
\text { joint ventures } \\
\text { - } \begin{array}{l}\text { Intense competition between } \\
\text { banks }\end{array} \\
\text { - } \quad \text { Rising interest rates and } \\
\text { failing spreads initially } \\
\end{array}$ \\
\hline & $\begin{array}{l}\text { - } \text { Deregulation of capital markets } \\
\text { - } \quad \text { Reduce government role in stock exchange } \\
\text { - } \text { Deregulation in insurance industries } \\
\text { - } \quad \text { Rationalisation of financial services sector } \\
\text { - } \text { Allowing fore igners to buy stock }\end{array}$ & $\begin{array}{l}\text { - Sharp increase in capital } \\
\text { markets activity and index } \\
\text { - Many companies were going } \\
\text { public }\end{array}$ \\
\hline \multicolumn{3}{|l|}{ Fiscal } \\
\hline $\begin{array}{l}\text { April, } 1984 \\
\text { Tax Reform }\end{array}$ & $\begin{array}{l}\text { - } \text { Remove holding tax, introduction of VAT } \\
\text { - } \quad \text { Rationalization of inco me and sales tax } \\
\end{array}$ & $\begin{array}{l}\text { Increased government } \\
\text { revenues }\end{array}$ \\
\hline \multicolumn{3}{|c|}{ Trade and shipping } \\
\hline $\begin{array}{l}\text { April, } 1985 \\
\text { Customs Reform }\end{array}$ & $\begin{array}{l}\text { - Removal of Customs Department in Goods } \\
\text { Clearance } \\
\text { - Appointment of Private Surveyor SGS } \\
\text { - Removal of restrictions on choice of } \\
\text { international carrier }\end{array}$ & $\begin{array}{l}\text { Reduced substantial average } \\
\text { time of imports and exports } \\
\text { clearance }\end{array}$ \\
\hline $\begin{array}{l}\text { March, } 1985 \\
\text { Tariff Rationalis ation }\end{array}$ & $\begin{array}{l}\text { Range reduction from } 0-22 \% \text { to } 0-60 \% \\
\text { Number of tariff levels reduced from } 25 \text { to } \\
11\end{array}$ & - $\quad$ Some reduction in protection \\
\hline May, 1986 & $\begin{array}{l}\text { Duty drawback and bypass monopoly } \\
\text { - Armslength transactions and computerized } \\
\text { processing }\end{array}$ & $\begin{array}{l}\text { Improve duty drawback } \\
\text { process }\end{array}$ \\
\hline
\end{tabular}

* Reform directly deal with BUMN

Sources: Mary Pangestu,"The Role of the Private Sectors in Indonesia: Deregulation and Privatization", Indonesian Quarterly, XIX/1, 1991.

Some data indicate that deregulation that was implemented before Asian crises brought positive impact in the economic growth until mid 1990s. In the period of 1980 1990, GDP growth rate reached a peak in 1989 in the point of $7.4 \%$. It was increased 2\% comparing with the year 1985, meanwhile exports of non-oil increased $30 \%$ in during the period of 1987 - 1988. In 1990, domestic investments reached 55\% of the total investments. Until 1996, Indonesian economic growth rate was still in the high level, it was $7.82 \%$, slightly higher than the average target of $7.10 \%$.

However, without any clear objectives, the practice of privatization itself did not work in the period of 1980s. It only took place in 1992 when PT Semen Gresik offered its shares in domestic market through Initial Public Offering - IPO. Even, in that period, it seems that no body was thinking about selling BUMN shares.

Asian crisis that hit Indonesian economy in mid 1997 resulted Indonesian economy to suffer and led to the budget deficit, high inflation, low growth and other negative impacts such as unemployment and increaseed the number of poverty. The instability became wide spread not only in the economy and politics, but also in the social sector. To recover from those situation, the government committed to accept International assistance from IMF 
which was the main assistancy institution. A package of recovery program must be implemented by government under the direction of IMF including privatization program.

Different from the period before crisis, government more applied the strategic sale methods during the crisis. A partial privatization of PT Semen Gresik took place in 1998. Through bidding process, $25.53 \%$ of PT Semen Gresik shares was sold out to Cementos Mexicanos S.A. (Cemex). Before it was sold, the shares of PT Semen Gresik was 65\% held by government, and 35\% free float on the Jakarta stock exchange. After the process of partial privatization, now government still stand as a majority holder with $51.01 \%$ shares, while the rest, $23.46 \%$ owned by public investors.

Pursued the 'succes' of privatization PT Semen Gresik, PT Telkom, PT Indosat and other 8 enterprises' shares were sold out to the public or to the certain investors. Table 3 summarizes BUMN privatized until end-2003.

Table 3. BUMN Privatized until December 2003

\begin{tabular}{|c|c|c|}
\hline Company & $\begin{array}{l}\text { Method of } \\
\text { Privatization }\end{array}$ & Pe rcentage of sale \\
\hline 1. Semen Gresik Group (SGG) & $\begin{array}{l}\text { Strategic Sale } \\
\text { Initial Public Offering }\end{array}$ & $\begin{array}{l}\text { Cementex Mexicanos }(25.53 \%) \\
\text { Public }(23.46 \%)\end{array}$ \\
\hline 2. PT Telkom ( $1^{\text {st }}$ round $)$ & Strategic Sale & PT Singtel (15\%) \\
\hline 3. PT Socfindo & Strategic Sale & PNS $(30 \%)$ \\
\hline 4. PT Indosat & Strategic Sale & STT (41.94\%) \\
\hline 5. PT Telkom ( $2^{\text {nd }}$ round $)$ & Accelerate placement & Public $(3.1 \%)$ \\
\hline 6. PT Tambang Batu Bara & $\begin{array}{l}\text { Initial Public Offering } \\
\text { Strategic Sale }\end{array}$ & $(16.5 \%)$ \\
\hline 7. PT Wisma Nusantara & Strategic Sale & $41.99 \%$ \\
\hline 8. PT Bank Mandiri & IPO & $20 \%$ \\
\hline 9. PT Bank Rakyat Indonesia & IPO & $\mathrm{Na}^{*}$ \\
\hline 10.PT Indocement & Secondary & $16.67 \%$ \\
\hline 11.PT Gas Negara & IPO & $\mathrm{Na}^{* *}$ \\
\hline
\end{tabular}

$\mathrm{Na}^{*}$ : percentage is not available. Govern ment earned Rp. 2.1 trillion.

$\mathrm{Na}^{* *}$ : percentage is not available. Govern ment earned Rp. 935 billion.

Source: Deputy of Restructuring and Privatization, Minisrtry of BUMN 
All enterprises in the table 3 are partial divesture, and recently still in the process of selling out their shares, as all of them are listed in the Jakarta stock exchange.

Simply, the reasons for privatization in practice could be divided into two:

\section{Internal Pressures}

The economic and social impact of crisis led the year to year budget deficit. These needs to be resolved. It caused the government consider other resources for covering the hole. Privatization of BUMN was the one of the resources that was esxpected to contribute revenues for that purposes. Following table presents the state budget surplus / deficits from year 1994/1995 to 2003.

Table 4. State Budget Surplus/deficit, 1996/1997 - 2003

\begin{tabular}{|lcccccccc|}
\hline Year & $1996 /$ & $1997 /$ & $1998 /$ & $1999 /$ & 2000 & 2001 & 2002 & 2003 \\
& 1997 & 1998 & 1999 & 2000 & & & & \\
\hline $\begin{array}{l}\text { Surplus/ } \\
\text { (Deficit) }\end{array}$ & $4,057.2$ & $(7,532.8)$ & $(16,260.7)$ & $(31,235.3)$ & $(16,132.2)$ & $(40,485.0)$ & $(40,453.7)$ & $(34,436.3)$ \\
\hline
\end{tabular}

Note : 96/97 - 1999 state budget period was 1 april to 31 March next year, year 2000, the period was changed to 1 April to 31 December in the same year, further 1 January to 31 December

Source: Ministry of Finance, Nota Perhitungan Anggaran Negara (State Budget Calcu lation), 1996 - 2003

The internal pressures also come from proponents of privatization of BUMN. While the lacking of managerial capability, absence of efficiency and productive methods and lack of managerial flexibility in the decision making process, resulted in the inefficiency of BUMN themselves. Those became worse when corruption in the government bodies deteriorated the illness of BUMN combining with the lack of transparency both government and BUMN concerning the policies and the financial of BUMN.

\section{External Pressures}

In order to help the economy recover, the government continued to request the financial assistance of IMF. An IMF package of recovery program came with preconditions and rules that must be followed by the government. The agreements, from October 31 to 10 December 2003, consists of more than 23 Leters of Intent including Memorandum of Economic and Financial Policies and its supplementaries. These can be summarized by:

\section{Financial sector restructuring}

2. Fiscal policy

3. Monetary policy 


\section{Structural adjustments / reforms}

Including in the agreement was privatization of some BUMN. The target must be achieved by Indonesian government proved to be formidable. During 1997 - 2002, the government at least must privatize 16 enterprises, including strategic enterprises such as PT Pupuk Kaltim, PT Kimia Farma, PT Telkom, PT Indosat, PT Angkasa Pura, and PT Semen Gresik Group. The proceeds expected totally Rp. 6.5 trillion per year during the period of 1997 - 2002. Although the target seemed quite high, in the budgetary plan 1999, the government even re-defined the target to Rp. 15 trillion that year which will come from the sell of 30 enterprises' shares.

Those two main pressures woke government up and set up a number of privatization policies after almost 20 years (1988 - 1997) privatization have implicitly been included as the tool of BUMN restructuring program.

\section{Analyzes}

In fact, it must be recognized that government earned the proceeds and received the additional profits contribution from BUMN. There are two impacts of Privatization Policy:

\section{Positive Impacts:}

1. Government earned some amount of Privatization proceeds

Figure 1. Proceeds of Privatization, 1994 - 2003

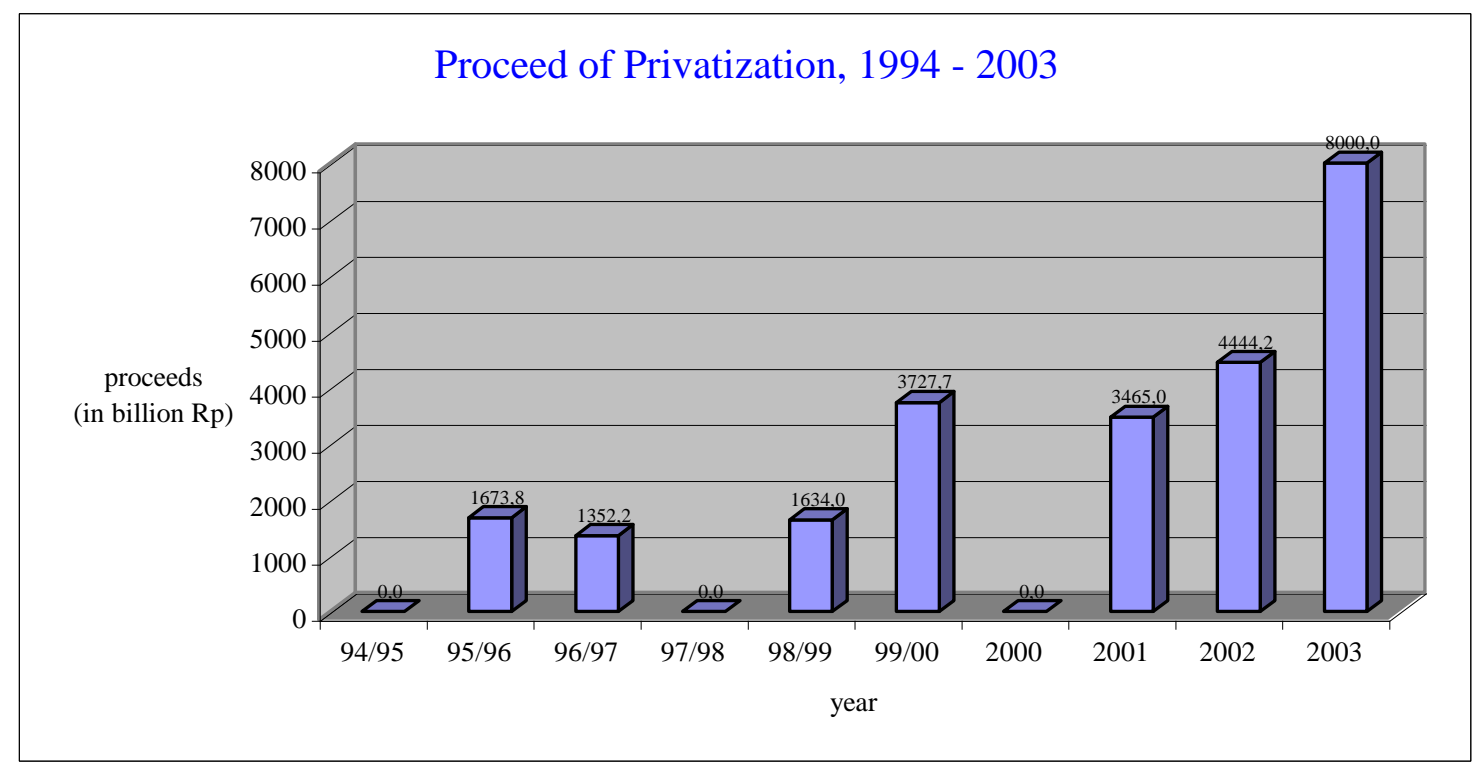

Note: year 2003- forecast

94/95 - 1999 state budget period was 1 april to 31 March next year, year 2000, the period was changed to 1 April to 31 December in the same year, further 1 January to 31 December

Source: Ministry of Finance, Nota Perhitungan Anggaran Negara (State Budget Calcu lation), 1994 - 2003

From figure 3 above, it is clear that the proceeds reached its peak on 2002 Rp. 4.4442 trillion. The expectation of Rp. 8.0 trillion in 2003 was not achieved, because enterprises that 
were privatized in 2003 denoted the the rest of enterprises planned to be privatized in the previous years (2001 and 2002). As clearly noted in the state budget, government have used the proceeds to cover the budget deficit. However, comparing to the huge amount of deficit, the contribution of privatization proceeds were not significant.

2. Increase of BUMN profits

State budget also indicates that the profit contribution of BUMN increased in significant number starting 1997, then in 2002 reached 0,5\% of GDP.

Figure 2. Profit Contribution of BUMN, 1994/1995 - 2003

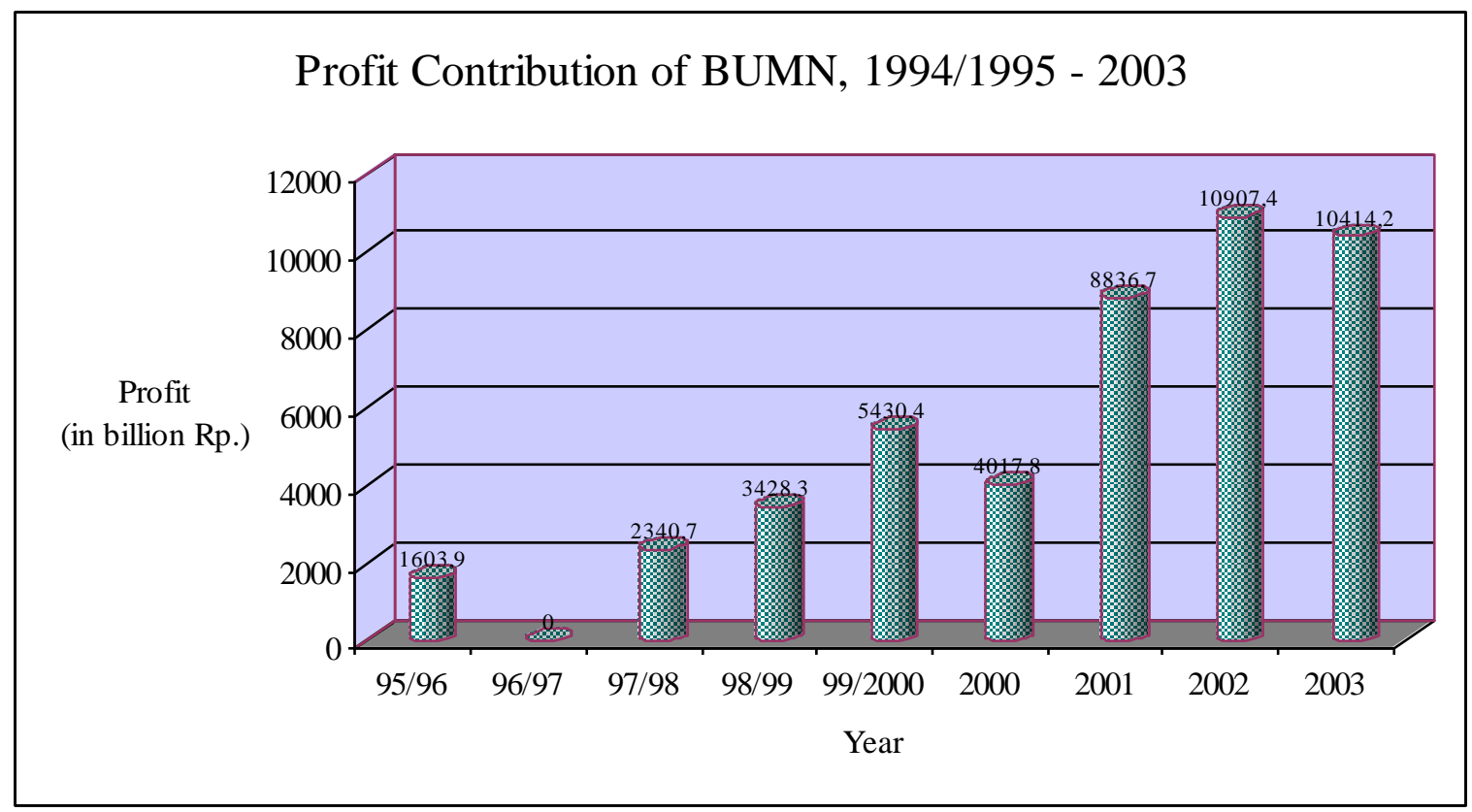

Note: $\quad 94 / 95$ - 1999 state budget period was 1 april to 31 March next year, year 2000, the period was changed to 1 April to 31 December in the same year, further 1 January to 31 December

Source: Ministry of Finance, Nota Perhitungan Anggaran Negara (State Budget Calculation), 1994 - 2003

Although the data provided in figure 4 does not distinguish more details about the proportion of profit contributed by privatized BUMN and contribution of BUMN that have not yet been privatized, in the state budget plan 2004 which was issued by Finance Ministry stated that the increased of profit contribution of BUMN mainly caused by the adoption of the privatization policy. The increase of productivity of the privatized enterprises was followed by the increased profit contribution from enterprises to the government.

\section{Negative Impacts:}

Protests from the opponents of privatization led to the instability of the political condition. Like in the other rest of the world, government were also facing some obstacles in implementing privatization policy. Resistance came not only from the side of employment 
who usually were worried about the issues of reducing employees. In the side of the government, privatzation even resulted conflicts among the member of House Representatives (DPR). For example in the case of PT Indosat partial privatization, the Chairman of Parliament Amien Rais raised a deep concern about that privatization process. President Megawati Soekarno Putri risked her chair resulting from the privatization policy, because many politicians use the issue of privatization in order to achieve their goals.

\section{Evaluation}

Although the privatization policy generated some proceeds, the revenues earned did not fulfil the government target. The fact that was most critized by the Indonesian economists and obsevers was the fact that the proceeds earned was far from the target as planned in the state budget, and did not meet the commitment agreed between Indonesia and IMF. As mentioned before, in the budgetary plan of 1999, the government have defined that Rp. 15 trillion must be received from the privatization of some BUMN. While according to the LoI that has been signed between Indonesian government and IMF, privatization proceeds should be Rp. 6.5 trillion per year during 1997 - 2002 in order to cover the budget deficit . Examining figure 3, it shows that the proceeds of privatization from year to year were always under-target.

Privatization program did not meet the objectives that were stated in the Master Plan of BUMN, Law of BUMN and other regulation concerning privatization of BUMN. Especially the point of widening the ownership of BUMN to the public. Describing in the table 8 , most method of the privatization was a 'strategic sale', through bidding process did not allow the public to participate or buy shares. In most cases, the government remained the major share holder. Selling through a bidding process only opened opportunities for big investors, but ignored public buyers.

The objectives mentioned in article 74 point (2) BUMN laws, "the purpose of privatization is to improve performance of BUMN and increase the participation of the society" was not achieved. The selling of certain number of BUMN shares were sold through a bidding process, or strategic sales, resulted to a few or single, new owner(s) and limited public buyers. (Pelase examine table 3 - in the column method of privatization).

Improving BUMN performance was not achieved optimally, as government only concentrated to privatize the healthy companies, but ignored other BUMN that are lacking in management. All enterprises that were included in the privatization program were already healthy companies, even if they are not privatized.

\section{Recommendation}

Considering the facts described above, I would recommend that: 
In order to achieve maximal objectives government should not be so ambitious in implementation of the privatization program. There were some evidence that the proceeds of privatization and the number of companies privatized are far from the target. The budget deficit as a result of Asian crisis could be understood. But selling out the shares of BUMN to cover the deficit without consideration of the price and social effects was not wise/irresponsible.

Privatization policy should be applied when the economic situation is stable and the growth is high. High growth rate leads to a good climate in the capital market. In this condition, when the prices of shares increase, selling out the shares will achieve its optimal goals.

Obstacles are very common when the government implements a certain policy. But the obstacles can be eliminated in the case of privatization in Indonesia. The protests can possibly be reduced if government treats all of 144 BUMN fairly. The poor BUMN must be restructured in order to help them improve their performance, increase their value and make them more profitable. The intern of the enterprises restructuring will allow them to have a better management system. Internal reforms also should be included for better control, independent financial auditors in order to reduce corruption practices in the body of BUMN.

Lastly, the government should be consistent with its objectives. Examining the background and results of privatization program, many objectives that were formed in the policy and master plan were not fully implemented. The objectives of privatization program implemented by government were only:

$\Rightarrow$ Generate revenues in order to fill the hole of budget deficits

$\Rightarrow$ Follow the IMF direction in order to get financial assistance

Indeed, the objectives are not wrong, but the raises questions: "Why were other written objectives ignored?" and "When will the other written objectives be achieved?". These are the open questions. 


\section{Bibliography}

Ali Frazmana, "Privatization or Public Enterprise Reform?", Greenwood Press, London, 2001

David Parker and David Saal, "International Handbook on Privatization", Edwar Elgar, Chelthenham, 2003

David Donaldson and Dileep M. Wagle, "Privatization - Principle and Practice", International Finance Corporation, Worldbank, Washington, 1995.

H. McLeod, Ross, "Privatization failures in Indonesia", Indonesia Project, Economics Division, The Australianj National University, Bulletin of Indonesian Economic Studies

Jeffrey Davis, Rolando Ossowski, Thomas Richardson, and Steven Barnett, "Fiscal and Macroeconomic Impact of Privatisation", IMF, Washington, 2000

Joseph E. Stiglitz et. al, "On the Economic Role of the State“, edited by Arnold Heertje, Blackwell, 1989

Mohamed Eliyas Hashim, "Privatisation Experience in Indonesia", in B.N. Ghosh, "Privatisation - The ASEAN Connection", Nova, NY, 2000

Peter Drysdale, "Reform and Recovery in East Asia - The Role of the State and Economic Enterprise", Eoutledge, London, 2000.

Russell Muir and Joseph P. Saba, "Improving State Enterprise Performance - The Role of Internal and External Incentives", Worldbank Technical Paper No. 306, Worldbank, Washington, 1995

Savas, E.S., "Privatization and Public-private Partnership", 2000

Soesastro Hadi, "Governance and the Crisis in Indonesia", in Peter Drysdale, "Reform and Recovery in East Asia - The Role of the State and Economic Enterprise", Routledge, London, 2000

Asian Development Bank Website, www.adb.org

Indonesian BUMN (SOEs) Website: www.bumn.co.id

IMF Website, www.imf.org

*)Alfiana Yuli Efiyanti, MA, Dosen Jurusan IPS, Fakultas Tarbiyah UIN Malang 